\title{
MORALITY AS A PSYCHOLOGICAL PROBLEM
}

\author{
Andrey V. Yurevich \\ Institute of Psychology of Russian Academy of Science \\ Moscow, Russia
}

The author states that the problem of morality should be one of the main topics of psychological science though modern Russian psychology avoids it for some reasons. The Institute of Psychology of the Russian Academy of Sciences develops the qualitative approach to this problem based on the index combining several statistic indicators. Applying it to modern Russian society provides the opportunity qualitative estimate of its state and dynamics. Using the qualitative data the author demonstrates the dramatic moral situation in modern Russia, describes its main causes and directions of improving.

Keywords: morality, qualitative estimate, dynamics, causes, consequences.

Morality is one of those problems which psychological science addresses infrequently and unwillingly. There are various reasons for this. One is that psychologists often perceive the problem as "assigned" to philosophy, primarily ethics, as one of its divisions. Another is that this problem can hardly lend itself to an empirical study and psychological laboratory "preparation." Yet another is that natural scientific psychology, in keeping with the natural science traditions, interprets objectivity of scientific investigation as implying an abstraction from values, which is hardly possible, if such problems as morality are to be studied.

Although many traditional objects of psychological investigations, such as values, attitudes, and others, have a direct relation to morals and morality, the problem itself somehow veered off the main course of the psychological problems. At the same time, a considerable part of psychological studies, including those pursued by the modern Russian psychological science, do address this problem, in particular, the moral state of modern Russian society - the aspect which is of most relevance for Russia today. 
Some available data, for example, indicate that the poll question "Can a person break the law and at the same time be right?" would induce Russian respondents to answer in the affirmative much more often than their opposite numbers do in the West. At the same time, the number of people holding, at least by word of mouth, that the laws must not be disobeyed under any circumstances, or the truly law-abiding citizens, has been practically unchanged during the last 15 years, accounting for some 10 to 15\% (Volovikova, 2004). Unlike in the Western countries, where moral and legal socialization is mostly achieved through following the socially accepted standards and laws, in Russia this process either "gets stuck" at the initial stage, where obedience is secured by the fear of punishment, or, bypassing the middle level, "shoots up" right to the top level characterized by reliance on the supreme ethical principles and conscience (Ibid.) ${ }^{1}$. Similar results can be derived from studying moral judgments of primary school students, who believe that human actions are mostly motivated by the fear of punishment and by compassion, with this explanation pattern remaining changed but little over the last 70 years (see: Kravtsova, 2005).

Some symptomatic results were yielded by psychological examinations targeting partially sane law-breakers. It turned out that what they understood by "freedom" was not staying in prison and/or being released from places of confinement, while existentially they viewed it as license and freedom from moral and public checks (Kudryavtsev, 2007).

A particularly worrisome picture arises from a probe into mind-sets of today's young people. A widespread phenomenon is ageism embracing negative stereotypes with regard to old age and aging, as well as the relevant discriminatory practices (see: Guddy \& Fiske, 2004. More often, the term "ageism" is used on a broader scale denoting any prejudiced

1 Margarita Volovikova, who obtained these results, is based on Laurence Kohlberg's classification that identifies three stages in human assimilation of moral norms: 1) they are observed out of fear of punishment, 2) they are followed in imitation, because everyone does so, 3) they are observed under the influence of inner ethical principles. Philosophy repeatedly came up with ideas identical to the ones in Kohlberg's classification. "Refrain from crimes not through fear but through duty," Democritus said. Oleg Drobnitsky wrote this to describe the mechanism for morals "internalization": "The individual as it were gradually imbibes public disapproval and approval, and becomes their conduit in his own right" (Sudakov, 1998, p. 252). 
attitude to age groups, including younger generations). Psychologists note that "currently a steady view has taken shape in Russia's society that relationships between age generations are passing through a stage of aggravation; specifically this concerns young people, on the one hand, and elderly or old people, on the other," something confirmed by numerous studies. It is also stated that in today's Russian society "intolerance to old age is displayed as intolerance to aged persons on the part of the younger generations and society as a whole."

"Studies show that a considerable part of immoral acts committed by young people is linked to their orientation to group standards that clash with the publicly accepted ones," as a result of which "young people express an ambivalent attitude to the necessity of obeying the social norms" (Bi-Bud, Zhalagina, \& Lelchitsky, 2008, pp. 136, 138). Though numerically those who reply that the standards must be obeyed prevail (we have reasons to doubt the sincerity of a majority of those respondents), at the same time one observes a widespread view to the effect that "we will abide by the laws and moral norms, if we can morally profit by doing so; when laws are made that correspond to modern personality's needs, and when it consciously observes those laws" (Shustova \& Gritsenko, 2007, pp. 55, 50). As long as it is more beneficial to disobey the laws and moral norms, the wish for the contrary remains an abstraction. Like any cognitive dissonance (Festinger, 1957), this discrepancy (an abstract recognition of certain norms and the actual conformity to other, often opposite, ones) is felt painfully by a person; it generates in him a sensation of inner disharmony that diminishes his satisfaction with life. This moral state of society is contributing to the sad statistics of nervous breakdowns, mental disorders, and suicides, whose incidence puts Russia in the second place in the world (Table 1).

Psychological studies that add to the depressing statistics of divorces, social orphanhood, the number of children born to broken families, and so on, bear witness to a crisis gripping the social institution of the family, the crisis that is also expressive of Russian society's moral state. It is noted that "the problems of the family and of family upbringing are as acute as never before in recent years: demographers, sociologists, culturologists, psychologists, and teachers confirm the existence of a profound system crisis eroding this social institution" (Bi-Bud, Zhalagina, \& Lelchitsky, 2008, p. 34). 
Table 1

Certain Indices of the State of Modern Russia's Society (2007 statistics) (sources: Doklad o razvitii cheloveka, 2007;

Rossijskij statisticheskij ezhegodnik, 2007)

\begin{tabular}{|l|c|l|}
\hline \multicolumn{1}{|c|}{ Name of Indicator } & $\begin{array}{c}\text { Value of } \\
\text { Indicator }\end{array}$ & \multicolumn{1}{|c|}{$\begin{array}{c}\text { Russia's Place } \\
\text { under this Indicator }\end{array}$} \\
\hline $\begin{array}{l}\text { Homicide mortality per } \\
100,000 \text { inhabitants }\end{array}$ & 20.2 & 1st place in Europe and CIS \\
\hline $\begin{array}{l}\text { Suicide mortality per 100,000 } \\
\text { inhabitants }\end{array}$ & 30.1 & $\begin{array}{l}\text { 2nd place in Europe and CIS after } \\
\text { Lithuania }\end{array}$ \\
\hline $\begin{array}{l}\text { Occasional alcohol poisoning } \\
\text { mortality per 100,000 inhabitants }\end{array}$ & 23.1 & 1 st place in Europe and CIS \\
\hline $\begin{array}{l}\text { Road accident mortality per } \\
100,000 \text { inhabitants }\end{array}$ & 17.5 & $\begin{array}{l}\text { 3rd place in Europe and CIS after } \\
\text { Lithuania and Latvia }\end{array}$ \\
\hline $\begin{array}{l}\text { Life expectancy at birth } \\
\text { (number of years) }\end{array}$ & 66.6 & $\begin{array}{l}\text { Last place among the countries } \\
\text { with an advanced and transitional } \\
\text { economies }\end{array}$ \\
\hline $\begin{array}{l}\text { Natural population growth per } \\
1,000 \text { inhabitants }\end{array}$ & -4.8 & $\begin{array}{l}\text { One of the last places in Europe } \\
\text { (before Bulgaria and Ukraine) }\end{array}$ \\
\hline $\begin{array}{l}\text { Number of children left } \\
\text { without parental care per } \\
100,000 \text { inhabitants }\end{array}$ & 89 & $\begin{array}{l}\text { 2nd place in East Europe and CIS } \\
\text { after Lithuania }\end{array}$ \\
\hline $\begin{array}{l}\text { Divorce numbers per } \\
1,000 \text { inhabitants }\end{array}$ & 4.5 & 1st place in Europe \\
\hline $\begin{array}{l}\text { Number of abortions per } \\
1,000 \text { women (15-49 years) }\end{array}$ & 40.6 & 1st place in East Europe and CIS \\
\hline $\begin{array}{l}\text { Share of children born by } \\
\text { unmarried women (\%) }\end{array}$ & 29.2 & $\begin{array}{l}\text { 9th place in East Europe and CIS } \\
\text { 1 st place among the countries } \\
\text { economies }\end{array}$ \\
\hline $\begin{array}{l}\text { Gini Coefficient (income } \\
\text { concentration index) }\end{array}$ & $\begin{array}{l}\text { 143rd position in the world } \\
\text { along with Gambia, Indonesia, } \\
\text { and Togo) out of 180 possible }\end{array}$ \\
\hline $\begin{array}{l}\text { Corruption Index (from 0 to 16, } \\
\text { the higher the point, the lower } \\
\text { the corruption level) }\end{array}$ & 0.4 and transitional \\
\hline
\end{tabular}

Some equally sad results are derived from psychological surveys of the business community: its members are unprepared for a socially responsible policy, which is perceived as running counter to their commercial interests. Moreover, the concept of social responsibility is interpreted in a totally different way by the business people and the main 
part of society, as became clearly evident during the current economic crisis. This creates the sociopsychological conditions not only for the inevitability of financial pyramids and other kinds of Russian businessmen's immorality, but also for a "cold civil war" between them and civil servants.

Generally, the psychological studies demonstrate that "Russia has been, for many years, a 'natural laboratory', where morality and legal consciousness stood a severe test" (Volovikova, 2004, p. 17).

Sociological surveys performed "on the brink" of social psychology throw light on a congenial picture, demonstrating, for example, a stark contrast between Russian and Western standards of behavior in public places. Western-trained Russian students and young specialists say it is good form over there to smile to people you do not know, "but when you bring the smile back home, it most often is left unrequited or proves out of place, and eventually it fades." A young woman come back home after an internship abroad observed this: "Everyone is gray and angry; they shove, and push, and swear. The rush down in the subway is a battle and a massacre. I was shocked, and I said to myself: 'My God, what a country I live in!” (Konstantinovsky \& Voznesenskaya, 2007, pp. 107, 108).

Irina Shcherbakova and Vladimir Jadov compared such a form of polite behavior as holding your subway entrance/exit door for someone who follows you in Moscow, St. Petersburg, Nizhny Novgorod, and Budapest. The worst behavior was found in Moscow, the best - in Budapest, where most often this was done by young people, while in Moscow middle-aged and older persons were in the lead. Some respondents in Russia compared a rush-hour underground travel to a fight for survival, where other co-travelers were perceived as rivals for your place in the train.

In 2006, Canadian sociologists made a study which demonstrated that in respect of helping behavior frequency, Moscow was way down the list of 48 world cities (see: Shcherbakova \& Jadov, 2007). Other comparative studies of everyday culture also indicate that people in Russia are clearly ahead of others where rudeness, aggressiveness and hatethy-neighbor feelings are concerned, with a tendency being observed towards even greater brutalization of public life. (Logically, the term "brutalization" is very much prominent in the professional vocabulary of Russia's sociologists.) Brutality spreads to every sphere of life, from 
marital relationships, where spouses hire killers to deal with family problems, to methods of suicide that become increasingly violent (Lysova \& Shchitov, 2003). Nearly 50\% of respondents in Russia admit that they are rude to others on a regular basis, seeing this kind of behavior as a social standard, with young and well-off persons practicing it most often (Klimov, 2006, p. 77).

Sociologists note that "in the late 20th and the early 21 st centuries, Russia's society that was plunged by the powers that be in the 'perestroika' and later in the 'radical reforms', constantly experienced moral deviations and a deficit of not so much social, economic and political orientations, values and behavior models, as moral ones." The same sociologists diagnose a "moral aberration" in Russia politicians' thinking and its distancing from moral values and orientations that have been superseded by categories of economic nature, such as economic growth, GDP size, inflation indicators, and the like (Levashov, 2007, p. 225).

According to the sociologists, "currently, in a situation, where the criminal subculture is expanding intensively to everyday life, the socium has few social restraining devices left that would make it possible to oppose the expansion. The normative system of the criminal world, a system actively relayed by the media and mass-culture products, is finding fertile soil in a society experiencing a deficit of social values (value anomie), while the disrespectful attitude to the formal juridical law, an attitude traditional for the Russian culture, can only make things easier for the 'invasion': today, as perceived by many citizens, it is the thieves' law that embodies justice." The following characteristic claims can also be found in sociological writings: "Elements of the criminal subculture are currently present, in one way or another, in all spheres of Russia society's life, from everyday life to rules of the organization of the economic or political 'game', from person-to-person relations to social institutions," "the criminal subculture has been massively invading, in recent years, the mass cultural product: movies and serials; thieves' songs are played on the air, in restaurants and cafes, as well as within the public conveyance system; detective stories and hits (filling all bookshops to the breaking point); and even mobile ring-tones" (Levashov, 2007, pp. 50, 38; Presnyakova, 2006), etc. It has been noticed that the main movie character is a "good" gangster ("The Boomer," "The Team," "The Brother," and others), not someone who fights crime. As is evident from polls, more than a half of Russia's inhabitants systematically use thieves' cant, 
etc. Each week, TV channels show over 60 news panoramas on criminal topics, and even members of the ruling element regularly resort to this kind of "discourse."

Sociologists also state the existence of an antagonistic confrontation between two types of morals: the morals of a rich minority and the morals of the poor majority (Levashov, 2007), although, of course, one can find many more types of morals and their "antagonistic confrontations" in Russia's socium.

\section{Quantitative Evaluation of the Moral State of Society}

The Russian Academy of Sciences' Institute of Psychology has developed, within the framework of the quantitative macropsychology (see, for example: Yurevich \& Ushakov, 2007; Yurevich et al., 2007) an investigative method of its invention - a moral state-of-society index (MSSI) based on the integration of such indices as the number (per 100,000 inhabitants) of:

1) murders,

2) neglected children,

3) a corruption index, and

4) the Gini coefficient used to estimate the unevenness of income distribution ${ }^{2}$.

The method of MSSI calculation is this. The primary indices are calculated as the basic ones. The value of Russia's 1996 indicator is taken as being equal to 100 points $\left(V_{0}\right)$. Normalization of the index values for later or earlier years $\left(V_{i}\right)$ is made by way of their correlation with the 1996 value (the higher the point, the better is the state of society in keeping with an appropriate parameter). To normalize the values of the indices of social orphanhood, homicide-caused mortality, and Gini coefficient, an increase in whose values points to a worsening state of society, this formula is used:

$$
Y_{i}=\frac{V_{0}}{V_{i}} \times 100,
$$

2 As is only natural, society's moral state is conveyed not only by these but also by some other indicators; it is these that appear as the most fitting indicators of its moral "temperature." The said parameters display a high correlation between themselves, which confirms the possibility of considering them as a manifestation of a single whole. 
To normalize the corruption index, an increase in whose values points to a better state of society, this formula is used:

$$
Y_{i}=\frac{V_{i}}{V_{0}} \times 100,
$$

where $V_{0}$ is the value of Russia's concrete 1996 indicator, $V_{i}$ is the value of this indicator for an appropriate year.

From 1996 on, the composite index is calculated as the geometric mean value of the four primary indices of

(i) homicide-caused mortality,

(ii) the identified numbers of children left without parental care,

(iii) corruption, and

(iv) income unevenness (Gini coefficient). Since the corruption index was not calculated prior to 1996, the composite index for 1990-1995 is based on the three primary indices.

Fig. 1 shows the dynamics of the thus evaluated moral state of Russia's society during the reform years.

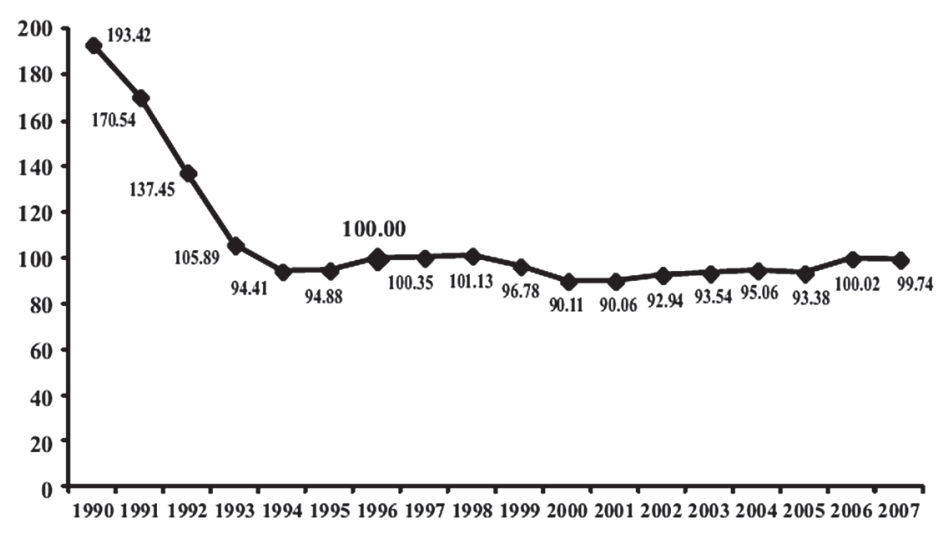

Figure 1. Dynamics of the Moral State of Modern Russia's Society

As can be seen from Fig. 1, the moral state of Russia's society was deteriorating annually from 1991 to 1994; after that it was improving right up to the default year of 1998; after that it was deteriorating anew 
till 2002; and then again it showed a tendency towards annual improvement (for 2008, the index was not calculated because of there being as yet no statistics for the basic calculus). Leaving aside any interpretations of the disclosed dynamics, I will just note that it almost fully correlates with the dynamics of the macropsychological state of modern Russia's society as evaluated on the basis of other indicators, as well as with a sociologically calculated time base of its characteristics (social moods, social optimism, and others), something indicative of the simultaneous manifestation of this sort of dynamics in most different spheres. A conspicuous fact is that the quantitatively evaluated moral state of Russian society during the first reform years was deteriorating at a fast rate, thus confirming that its deterioration was linked precisely to the reforms and the accompanying events; during the subsequent years it was just over one-half of the 1990 level, even though it did show a nonlinear, wave-like dynamics.

As quantitatively evaluated by the above method, the moral state of Russia's society reveals high correlations with its other characteristics, in particular with the main indicators of its innovation activity (Table 2).

Table 2

\section{Connection between Moral State of Russia's Society and Innovation Activity Indicators}

\begin{tabular}{|l|c|}
\hline \multicolumn{1}{|c|}{ Innovation Activity Indicators } & Pearson Correlation Coefficient \\
\hline Number of patents per i million inhabitants & 0.539 \\
\hline $\begin{array}{l}\text { Innovative products as a share of overall } \\
\text { production }\end{array}$ & 0.888 \\
\hline $\begin{array}{l}\text { Number of advanced technologies in use } \\
\text { per 1 million inhabitants }\end{array}$ & 0.939 \\
\hline $\begin{array}{l}\text { Number of advanced technologies developed } \\
\text { per 1 million inhabitants }\end{array}$ & 0.574 \\
\hline
\end{tabular}

Data in Table 2 are demonstrative of the "material nature" of the moral state of society, and, specifically, its considerable role in creating the prerequisites for an innovation-driven economy that various state programs (Koncepcija dolgosrochnogo social'no-jekonomicheskogo razvitija..., 2008) direct Russia’s society to achieve. 


\section{Consequences of Moral Decadence}

The "materiality" and the pragmatic nature of the moral-state problem that the strategists of reforms in Russia normally either ignore or put on the back burner as due to be addressed "in the wake" of the economic agendas ${ }^{3}$ have been demonstrated by different sciences.

Sociological studies indicate that the purely economic birth-rate enhancement measures may yield 15-20\% growth (Boyko, 1985), because the unwillingness to have children is mostly influenced by noneconomic factors. A principal one, according to polls, is the reluctance to give birth in this country, whose moral ill-being is emphasized by the respondents.

Aleksey Shevyakov says that "the shifts in birth- and mortality-rate tendencies in Russia are due, to some $85-90 \%$, to the excessive inequality and a high relative poverty of the population," things testifying to the moral state of society. He stresses that the "connection between socioeconomic factors and the demographic indices is mediated by human psychological reactions and behavioral attitudes ensuing from those reactions" (Shevyakov, 2008, pp. 305, 308.). Viktor Levashov explains Russia's current "disastrous depopulation" by the "moral gap existing between society and the state" (Levashov, 2007, p. 259).

To quote Ruslan Grinberg, "demographic studies demonstrate that more than two-thirds of things that cause Russia's depopulation are linked to such post-Soviet sociopsychological phenomena as social depression, apathy, and aggression" (Grinberg, 2007, p. 588), some of which (e.g., mass-scale aggressiveness) are direct manifestations of the decay of morality, while others (apathy, depressive states, etc.) are massscale psychological reactions to its decay. In particular, the permanent feeling of one's environment's immorality, hostility and aggressiveness tends to cause stress, apathy, depression, and so on, which, in turn, generate mental disorders, nervous system breakdowns, cardiovascular,

3 This style of thinking and viewing things in society that emphasizes the economy and dismisses the rest, including morality, as being of secondary importance was given the name of "economic determinism." It was exposed to harsh criticism by Alexis Tocqueville, Karl Polanyi and many other thinkers, while Mark Rats described it as a "hangover of Marxism"; he stressed that "the focus on economics" derived from Marxian dividing of society into the economic basis and a social superstructure, inferior in significance (see: Rats, 1997). 
gastrointestinal, and other diseases. According to WHO statistics, from $45 \%$ to $70 \%$ of all ailments are linked to stress, while such psychosomatic diseases as neuroses, cardiovascular disturbances, ulcer lesions of the gastrointestinal tract, immunodeficiencies, endocrinopathias and tumor diseases are revealed as being directly dependent on it (Sudakov, 1998). By analogy with the psychosomatics, there is every reason for introducing the concept of sociosomatics as representing the influence that the moral state of society has on the physiological processes in the human organism ${ }^{4}$.

Moral decadence figures prominently among suicide motives and is directly related to the depressing statistics of drug abuse, alcoholism, accidents, and so on, which are the main manifestations of Russian society's physical self-destruction. Aleksandr Myagkov and Sergey Yerofeyev note that "social integration theories traditionally view suicide rate growth as an important sign of rising tensions and self-destruction in society, which are, in turn, a consequence of deep-going deviations in social structures and of the lack of value-normative unity" ${ }^{\text {. They also }}$ state that the "continuing suicide rate growth is the price we have to pay to this day for our uncivilized form of transition to the market" (Myagkov \& Yerofeyev, 2007, pp. 54, 50).

Some identical regularities can be traced in history. Lev Kudryavtsev says that "history offers numerous examples, starting from the fall of the Roman Empire, where on the whole economically safe states collapsed in consequence of declining public moral standards" (Kudryavtsev, 2000, p. 9). Based on the crucial historical cycles in the evolution of the Russian state, Boris Kuzyk shows that all of its political and economic ups and downs were preceded accordingly by ups and downs in spiritual life and morality (see: Bogomolov, 2008).

Contrary to Russia reformers' claims postulating the "redundancy" of morality in a market economy, the connection of the latter two is more than obvious and was demonstrated way back by Max Weber and his followers in their classical works. It is equally obvious for business people.

4 In this sense, some interesting data are provided by the demographers; a case in point is that the disintegration of the USSR led to a 0.5 -centimeter height reduction in newborn infants.

5 This tradition springs from Emile Durkheim's classical work Suicide: A Study in Sociology (New York, 1951). 
Sergey Petrov of Rolf Group underscores that the "moral exigencies are not an extra load of sorts being imposed on Business by certain public forces, that is, from the outside, but are a pledge of its successful development." The law to the effect that "the higher the moral development level of the mass of population, the more successfully a country's economic and political system develops" and "the state of the economy is directly dependent on a personality's spiritual and moral state" receives most diverse and more than convincing confirmations.

Morality also has a substantial impact on the sociopolitical system of society. In particular, it is hard to disagree with the claim that "ethics is the heart of democracy" (Bogomolov, 2008, pp. 422, 367, 19) since the latter implies citizens' confidence in its institutions, which is impossible without the institutions being made to abide by the fundamental ethical principles. To quote the former USSR President Mikhail Gorbachev, "any system will be doomed, if it lacks the moral component" (Gorbachev, 2008, p. 14). Metropolitan Cyril put it in an even more categorical form: "Morality is the condition of survival for the human civilization - no more, no less" (Bogomolov, 2008, p. 372).

\section{What Is ToBe Done?}

Despite some positive shifts during the last few years, Russia's society is still traumatized by the chaos, while one of its main problems is not the deficit of freedom that the West constantly accuses us of (misunderstanding, as usual, the developments in Russia), but a diametrically opposite thing, to wit, the deficit of control, primarily inner, or moral, control. This is the key need as far as Russia's society is concerned, and it is refracted by the mass consciousness as follows. As is evident from polls, the overwhelming majority of Russians favor the tightening of laws, moral media censorship (that its opponents palm off as ideological censorship, thus intentionally substituting the notions) and other forms of moral surveillance. Similar intentions are observed within the power agencies and in the Public Chamber, whose members say that "the main problem in modern Russia is a decline of moral culture," etc. All of this indicates that an appropriate need has ripened in Russia's society.

To be sure, it would be absurd to try and give a simple answer to the traditional Russian question "What is to be done?" as applied to the 
moral state of Russia's society as it is today. It is also obvious that the declarative calls for a revival of morality and morals are like a voice of one crying in the wilderness. Moreover, given the nihilism professed by a considerable part of the younger generation, whom the pseudoliberal ideologems have inured to doing "the opposite" of what the older generations urge them to do, they are likely to produce a totally different effect. Says Oleg Bogomolov: "Thus far, the progressive public, both in this country and in the West, continues sounding an alarm over the deep moral crisis. But the ways of overcoming it are unclear" (Bogomolov, 2008, p. 368).

Nevertheless, some key paths leading to a moral revival can well be indicated.

- First, it is necessary to revise the concept of freedom that we inherited from the first reform years; in today's Russia its nature is highly distorted. Freedom implies reasonable restrictions that are interiorized by citizens. This understanding of freedom, which can be gleaned from the works written by Immanuel Kant, Ivan Ilyin ${ }^{6}$ and other outstanding thinkers, should be inculcated in the people's minds in Russia with the help of the education system, that currently pays clearly insufficient attention to these works and the appropriate problems.

- Second, it is necessary to revive the institutions of moral control that are practically absent in today's Russian society. One should hardly seek to create institutions resembling the Soviet Party and Komsomol organizations (not that it would be possible in a democratic society either), but both schools, and universities, and mass organizations might perform the moral control function, for which they need society's mandate. For example, it stands to reason to make university enrolment and the staying on the student body dependent on how students behave within and outside of the university walls. The mass organizations, in-

6 Specifically, Ivan Ilyin asked this question: "What will be done with the political freedom by a person who is not ripe for it and experiences it as license?" And he replied: "He himself becomes a most dangerous enemy of other people's and general freedom" (Ilyin, 1991, p. 146). Let us also note that this understanding of freedom that spread in Russia early in the 20th century, and subsequently in the 1990s, is not a Russian "invention." For example, freedom advocated by the French salons in the Enlightenment epoch "was of a purely negative nature and degenerated into the freedom to negate all moral statutes" (Lektorsky, 2008, p. 412). 
cluding the leading political party, ought to attach more importance to moral qualities of their members.

- Third, Russia's society being characterized by the dearth of inner (or moral) regulators, their "externalization" should be resorted to, by way of legislatively conferring the status of laws on moral norms ${ }^{7}$.

- Fourth, it is necessary to decriminalize Russia's society and its everyday culture. In particular, the decriminalization of mass consciousness implies not only the cleansing of vocabulary from the thieves' cant, etc., but also a radical change in relationships between the population and the law-enforcers, including the attitude to tipping them off on breaches of law, which, in Russia's culture, under the obvious influence of the criminal world, is perceived as "denunciation" . We still do not know how to distinguish between ideological denunciation and reports about breaches of law, which, in effect, are manifestations of civic responsibility that does not regard "small" infringements as unimportant and not meriting the law enforcers' attention. Besides, there is no such concept as "professional criminal," even though many people in this country are capable of engaging in criminal activities alone while out of prison and do not conceal the fact.

- Fifth, it is necessary to invite a large number of scientists - sociologists, psychologists, and others-to take part in lawmaking, the kind of work that in Russia is only regarded as the purview of professional lawyers and omnipresent politicians (the fact that legislatures at all levels have numerous athletes and showmen as members, who expand the social base of the legislators, can only worsen the situation). Laws are not

7 A graphic case in point is a bill approved by the State Duma that banned the consumption of beer and mildly alcoholic drinks in public. In this (very instructive) instance, the inner (moral) ban was externalized. And this worked, although in line with the Russian attitude to laws: Russians did not stop drinking beer in public but did so much less frequently than in the absence of a legal ban.

8 Finland's example is instructive in this sense (Finland has been recognized as the world's least corrupt country). A cornerstone of its anticorruption fight is the simplicity and easiness of informing the law enforcers about all cases of corruption (in Russia the term "denunciation" would pop up immediately). Any citizen can do so via the Internet without filling in any forms or running into bureaucratic barriers. The authorities would blacklist the officials exposed as corrupt, and this would strip them of any chance to get a decent job in the future. 
simply legal norms; they are the most general rules of social interaction that should be drawn up and introduced with account taken of social, psychological, economic and other regularities disclosed by the appropriate sciences.

It can be easily forecast what fierce resistance to these measures would be put up by Russia's pseudoliberals ${ }^{9}$, who distorted the reasonable understanding of freedom to the utmost, and by those criminalized social strata that stand to benefit from it. But in this case, the risk of new ideological collisions is clearly justified: after all, "whether we want to admit it or not, morality really lies at the base of everything," and, in particular, "it is high time we realized that in Russia the moral education and spiritual revival are matters of national survival and a necessary prerequisite of economic recovery" (Bogomolov, 2008, pp. 375, 20).

\section{References}

Bi-Bud, B., Zhalagina, T., \& Lelchitsky I. (Eds.). (2008). Social'nye riski v sovremennom polikul'turnom obshchestve [Social Risks in Modern Polycultural Society: Psychological and Pedagogical Aspects]. Tver'.

Bogomolov, O. (Ed.) (2008). Jekonomika i obshchestvennaja sreda: Neosoznannoe vzaimovlijanie [Economics and Public Milieu: Unrealized Mutual Influence]. Moscow: In-t jekon. strategij.

Boyko, V. (1985). Rozhdaemost': social'no-psihologicheskie aspekty [Birth Rates. Sociopsychological Aspects]. Moscow: Mysl'.

Doklad o razvitii cheloveka: 2007/2008 (2007) [Human Development Report 2007/2008]. Published for UN Development Program (UNDP). Moscow: Ves' Mir.

Festinger, L. (1957). A Theory of Cognitive Dissonance. Stanford, CA.

Gorbachev, M. (2008). Strashnaja jekonomika [The Fearsome Economy]. Mir peremen [World of changes], 4, 11-14.

Grinberg, R. (2007). Pjatnadcat' let rynochnoj jekonomiki v Rossii [Fifteen Years of the Market Economy in Russia]. Vestnik RAN [Russian Academy of Science Herald], 77(7), 584-592.

9 "Pseudo," because the Russian Liberal Manifesto (authored by the leaders of Soyuz Pravykh Sil - the Union of Right Forces) styles the writers as followers of the avowed Russian liberals Boris Chicherin, Mikhail Speransky, and Sergey Witte, each of whom would be shocked to learn what kind of individuals are described as liberals in modern Russia. 
Guddy, A.J.C., \& Fiske, S.T. (2004). Doddering but Dear: Process, Content and Function in Stereotyping of Older Persons. In T.D. Nelson (Ed.), Ageism: Stereotyping and Prejudice against Older Persons. Cambridge, MA.

Ilyin, I. (1991). O grjadushchej Rossii [On Russia’s Future]. Moscow.

Klimov, I. (2006). O hamstve i hamah. [On Boors and Boorishness]. Sotsial'naya real'nost' [Social Reality], 7-8, 77.

Koncepcija dolgosrochnogo social"no-jekonomicheskogo razvitija rossijskoj federacii na period do 2020 goda [Concept of Long-Term Socioeconomic Development of the Russian Federation for the Period till 2020] (2008). Moscow.

Konstantinovsky, D., \& Voznesenskaya, Ye. (2007). Obrazovanie za rubezhom: sociokul'turnyj aspekt [Education Abroad: Sociocultural Aspect]. Sotsiologicheskij zhurnal [Sociological Journal], 4, 97-114.

Kravtsova, M. (2005). Sravnitel'nyj analiz moral'nyh suzhdenij mladshih shkol'nikov (1930 i 2000 gg.) [Comparative Analysis of Moral Judgments of Junior School Children (1930 and 2000)]. Voprosy psihologii [Psychology Issues], 5, 27-36.

Kudryavtsev, I.A. (2007). Nravstvennaja sfera soznanija ogranichenno vmenjaemyh pravonarushitelej [Moral Sphere of Consciousness of Partially Sane Offenders. Part 2]. Psihologicheskij zhurnal [Psychological Journal], 3, 76-95.

Kudryavtsev, L. (2000). Sovremennoe obshchestvo i nravstvennost' [Modern Society and Morality]. Moscow: Nauka.

Lektorsky, V. (Ed.) (2008). Filosofija. Nauka. Kul'tura. "Voprosam filosofii” 60 let [Philosophy. Science. Culture. 60 years anniversairy of "Philosophical Issues"]. Moscow: Veche.

Levashov, V. (2007). Sociopoliticheskaja dinamika rossijskogo obshchestva. 20002006 gg. [Sotsiopolitical Dynamics of Russia's Society: 2000-2006]. Moscow: Academia.

Lysova, A., \& Shchitov, N. (2003). Sistemy reagirovanija na domashnee nasilie: opyt SShA [Systems of Reacting to Family Violence: USA experience]. Sotsiologicheskij zhurnal [Sociological Journal], 3.

Myagkov, A., \& Yerofeyev, S. (2007). Samoubijstva v Ivanovskoj oblasti: Analiz vremennyh trendov [Suicides in Ivanovo Region: Analysis of Temporal Trends]. Sotsiologicheskij zhurnal [Sociological Journal], 2, 37-58.

Presnyakova, L. (2006). Skromnoe obajanie kriminala protiv tshchetnyh usilij tjur'my [The Discrete Charm of Crime vs the Futile Efforts of Prison]. Sotsial'naya real'nost' [Social Reality], 1, 38-50.

Rats, M. (1997). Ideja otkrytogo obshchestva v sovremennoj Rossii [The Idea of Open Society in Modern Russia]. Moscow: Magistr.

Rossijskij statisticheskij ezhegodnik. 2007 [Russian Statistical Yearbook. 2007]. Moscow: Rosstat. 
Shcherbakova, I., \& Jadov, V. (2007). Kul'tura predupreditel'nogo povedenija $v$ bolshom gorode: Opyt videonabljudenija passazhirov u dverej metro Budapeshta, Moskvy, Nizhnego Novgoroda i Sankt-Peterburga [Culture of Obliging Behavior in Big City: Practicing Video Monitoring of Passengers at Subway Doors in Budapest, Moscow, Nizhny Novgorod, and St. Petersburg]. Sotsiologicheskij zhurnal [Sociological Journal], 4, 138-148.

Shevyakov, A. (2008). Neravenstvo i formirovanie novoj social'noj politiki gosudarstva [Inequality in Forming New Social Policy of the State]. Vestnik RAN [Russian Academy of Science Herald], 78(4), 304-316.

Shustova, N., \& Gritsenko, V. (2007). Social'no-psihologicheskaja adaptacija molodezhi i otnoshenie k social'nym normam [Sociopsychological Adaptation of Young People and Their Attitude to Social Norms]. Psihologicheskij zhurnal [Psychological Journal], 28(1), 46-57.

Sudakov, K. (1998). Individual'naja ustojchivost' k jemocional'nomu stressu [Individual Resistance to Emotional Stress]. Moscow: Gorizont.

Volovikova, M. (2004). Nravstvenno-pravovye predstavlenija v rossijskom mentalitete [Moral-Legal Representations in Russian Mentality]. Psikhologicheskij zhurnal [Psychological Journal], 5, 16-23.

Yurevich, A. et al. (2007). Kolichestvennaja ocenka makropsihologicheskogo sostojanija sovremennogo rossijskogo obshchestva [Quantitative Estimate of the Macropsychological State of Modern Russian Society]. Social Sciences, 4.

Yurevich, A., \& Ushakov, D. (2007). Makropsihologija kak novaja oblast' psihologicheskih issledovanij [Macropsychology as a New Area of Psychological Studies]. Voprosy psihologii [Psychology Issues], 4, 3-15. 